Dom. Cien., ISSN: 2477-8818

Vol. 4, núm.4., oct, 2018, pp. 3-24

\title{
Cost-benefit analysis of dollarization, Ecuador case
}

\section{Análisis costo-beneficio de la dolarización, caso Ecuador}

\section{Análise custo-benefício da dolarização, caso do Equador}

\author{
Carmen Álvarez-Vásquez ${ }^{\mathrm{I}}$ \\ carmenalvarezavz@hotmail.com \\ Víctor F. Guaranda-Sornoza II \\ victor.guaranda@unesum.edu.ec \\ Lilian del Jesús Aguilar-Ponce ${ }^{\mathrm{III}}$ \\ lilian.aguilar@educacion.gob.ec
}

Antonio E. Pinargote-Vásquez IV

antonio.pinargote@unesum.edu.ec

Diana K. Zambrano-Ponce V dianaj1982@hotmail.com

Jessenia H. Morán-Chilán VI

jessenia.moran@unesum.edu.ec

Recibido: 27 de junio de 2018 * Corregido: 28 de agosto de 2018 * Aceptado: 15 de septiembre de 2018

I. Master en Marketing Digital y Comercio Electrónico, Master en Docencia Universitaria e Investigación Educativa, Ingeniera Comercial. Docente Universidad Estatal del Sur de Manabí, Jipijapa, Ecuador.

II. Maestrante de Tecnologías de la Información, Economista. Ingeniero en Computación y Redes. Docente de la unidad de Nivelación en la Universidad Estatal del Sur de Manabí, Jipijapa; Ecuador.

III. Magister en Auditoria Integral, Universidad Técnica Particular de Loja. Economista, Universidad Estatal del Sur de Manabí. Licenciada en Análisis de Sistemas, Universidad Laica Eloy Alfaro de Manabí, Jipijapa; Ecuador.

IV. Ingeniero en Auditoria, Universidad Estatal del Sur de Manabí. Licenciado en Análisis de Sistemas. Universidad Laica Eloy Alfaro de Manabí, Jipijapa; Ecuador.

v. Economista, Universidad Estatal del Sur de Manabí. Especialista en Contratación Pública y control Gubernamental, Universidad de Guayaquil, Guayaquil, Ecuador.

VI. Master en Economía Agraria. Economista. Docente de la Carrera de Contabilidad y Auditoría. Universidad Estatal del Sur de Manabí, Jipijapa; Ecuador. 


\begin{abstract}
This paper analyses the reasons why Ecuador changed its monetary policy by substituting the national currency Sucre by US Dollar; the benefits and costs of dollarization in Ecuador; examines economic performance by using data collected by the Central Bank and International database available, the period from 1996 to 2007 have been chosen for this study; and uses variables like GDP, Foreign Direct Investment, Debt, Taxes and Inflation.
\end{abstract}

Keyword: Dollarization, cost- benefit analysis, economic analysis, Ecuador.

\title{
Resumen
}

Este articulo analiza las razones por las cuales Ecuador cambió su política monetaria al sustituir la moneda nacional Sucre por el dólar estadounidense; los beneficios y costos de la dolarización en Ecuador; examina el rendimiento económico utilizando los datos recopilados por el Banco Central y la base de datos internacional disponible; el período de 1996 a 2007 se eligió para este estudio; y utiliza variables como PIB, Inversión Directa Extranjera, Deuda, Impuestos e Inflación.

Palabras Clave: Dolarización, análisis costo-beneficio, análisis económico, Ecuador. 


\section{WWhy dollarize?}

There are mainly two ways to promote currency stability in a country, for most of the countries the optimal way to achieve this stability has been to peg their local currency to a major convertible currency, another option is full dollarization, a situation in which a country abandons its own currency and adopts another country's currency as a means of payment and unit of account

(Bank, 2000)

\section{Introduction.}

Dollarization processes arise in a country as a result of a loss of confidence in the traditional functions of local currency. Adopting total dollarization of an economy as a policy implies replacing $100 \%$ of the local currency with foreign currency, which means that prices, salaries, and contracts are set in dollars.

Total dollarization rests on some specific principles:

- The single currency is dollar and local currency disappears. In the case of Ecuador, it is contemplated that the local currency circulates only as a fractional currency.

- Monetary offer is denominated in dollars and feeds on the balance of payments and an initial amount of international reserves;

- Capitals are free to enter and exit without restrictions;

- The Central Bank restructures its traditional functions and acquires new functions.

In short term, the benefit of dollarizing is that hyperinflation would be stopped in its tracks. Ecuador suffered double-digit inflations over twenty years, but after dollarization in 2000, the average inflation hardly reached $3.8 \%$. Since then, per capita income has grown $114 \%$, freeing more 
than three million Ecuadorians from extreme poverty. The performance of dollarized Ecuador is among the best in South America.

When an underdeveloped country, with low productivity, adopts the currency of an economic power that far exceeds it in levels of productivity, hardly the agricultural or industrial production of the dollarized country can compete internationally. Like Venezuela, Ecuador is an oil country and when dollarized, they lose their ability to adjust the exchange rate to support the competitiveness of non-oil exports. Rafael Correa could not support the exchange competitiveness of non-oil exports through the management of exchange rate policy.

Once inflation problem was solved, the real wage recovered and the level of poverty reduced, Correa wanted to eliminate dollarization in Ecuador because he could not expand the economy through an increase in public spending and the expansion of liquidity. Therefore, when evaluating the advantages and disadvantages of dollarization, it is necessary to identify and analyze what would be the new sources of public expenditure financing, since there would be no room for maneuver the management of monetary policy for economic expansion. .

This paper focuses in the conditions and implications that impacted the Ecuadorian economy after the process of dollarization, it measures the benefits like the reduction of inflation, GDP growth, and investment trends; also analyses costs, like the absence of monetary policy and its repercussions.

\section{Ecuador Background}

By the end of 1999, Ecuador was facing perhaps the biggest economic crisis in its history as a republic. The Sucre, the official currency of the country, reached a 95\% of devaluation (Erazo,

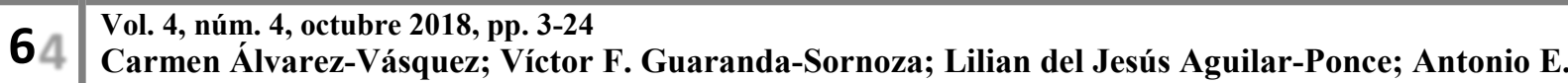
Pinargote-Vásquez; Diana K. Zambrano-Ponce; Jessenia H. Morán-Chilán
} 
2010); prices were incrementing $30 \%$ monthly on average which was leading the country to hyperinflation; as result of the government intervening in the banking system, a big amount of deposits were frozen. The country was facing large fiscal deficits and increasing internal debt which led to imbalances, additionally, world oil prices were declining; El Niño ${ }^{1}$, a natural phenomenon that hit Ecuador in 1998, caused devastating impact on production and infrastructure.

In addition to those circumstances, internationally, Ecuador delayed payments to private creditors and as consequence of this the International Monetary Fund didn't lend money to the country for almost a year, resulting in extreme monetary instability.

Due to this instability, on January the $9^{\text {th }}$ of 2000 , the Ecuadorian Government, leaded by Jamil Mahuad which was the elected President since 1998, decided to adopt the US dollar as the national currency. Because of the instability the country was facing, and policies the president was implementing, Mahuad lost popularity very quickly and by January $21^{\text {st }}$ of 2000 was removed from office by thousands of protesters, mostly indigenous people from the Ecuadorian highlands. The vice-president Gustabo Noboa was positioned as the new president; nevertheless, the new Government ratified the dollarization policy as a way to promote economic stability. Finally, the exchange rate was fixed at 25,000 sucres per US dollar.

In current situation of monetary stability and economic growth in Ecuador, It is important to emphasize the circumstances at the time when dollarization began. The dollarization was the last desperate attempt by the government to stabilize the economy after many other policies that had been tried and had failed during a long period.

\footnotetext{
${ }^{1}$ El Niño, is a climate pattern that describes the unusual warming of surface waters in the eastern tropical Pacific Ocean. In most countries, such as Peru, Ecuador, Papua New Guinea and Kenya, El Niño has had the largest impact at the community and household level, particularly among the vulnerable populations. Natural disasters stress traditional coping mechanisms within communities and households. 
Benefits

\section{Reduction of Inflation}

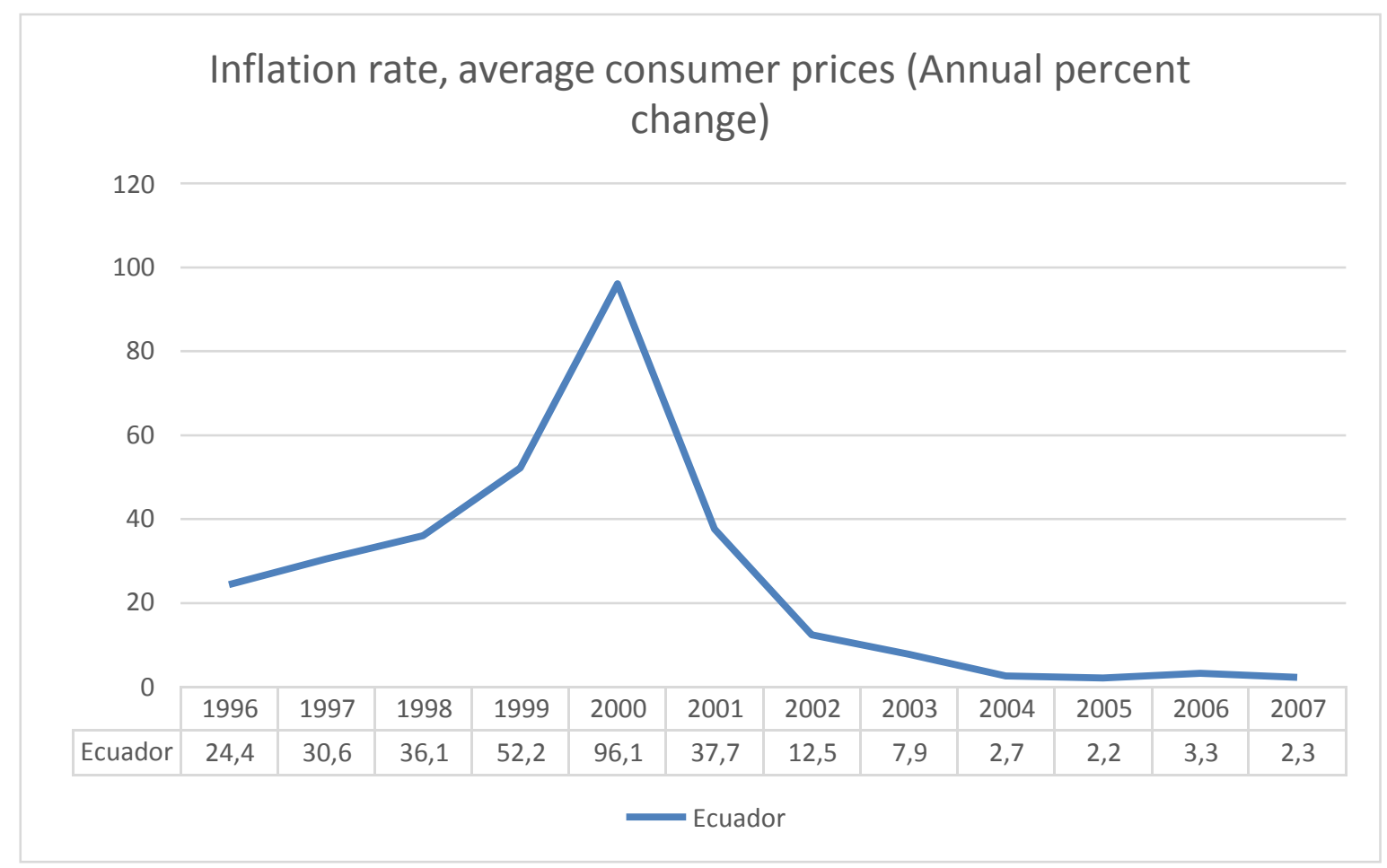

Source: IMF

By adopting a stable international currency such as the US dollar, inflation would be explicitly managed by the US Federal Reserve with price changes in the dollarized economy being closely linked to United States monetary policy. The success of inflation control, of course, would be contingent on a continued prudent monetary policy of the United States. (Alan Karnovitz, 2010)

High levels of inflation derivate in negative consequences, including, loss of acquisitive power, loss of savings, raise of interest rates and loss of competitiveness.

\footnotetext{
84 Vol. 4, núm. 4, octubre 2018, pp. 3-24 
Fundamentally, dollarization was implemented in Ecuador as a measure to stop the high levels of inflation, which by 2000 reached $91.1 \%$. The inflation rate is one of the indicators that shows the biggest contrast in the 1996-1999 and 2000-2006 periods, the periods before and after dollarization. Monetary change was substantially important in control of inflation rates, without underestimating other important factors that also had an impact in the evolution of prices.

In the first year of dollarization de percentage of the monthly variation of Consumer Price Index shows high values for an economy which currency is the US dollar and where the Central Bank is unable to emit new coins. By 2001 inflation starts to decelerate and by 2003 inflation reach the one digit goal.

After dollarization, annual inflation rate decreased drastically, went from $96.1 \%$ in 2000 reaching $2 \%$ in 2004 and get stabilized under 5\% in the upcoming years.

Is considered that dollarization reduced inflationary pressures due to the fact that the change of currency eliminated the exchange-rate risk. Dollarization was a tool, which achieved not in the short term but in the medium term, a considerable reduction of inflation which led to a sense of economic stability. But dollarization was just one of the necessary reforms to assure sustainable growth. 
GDP Growth

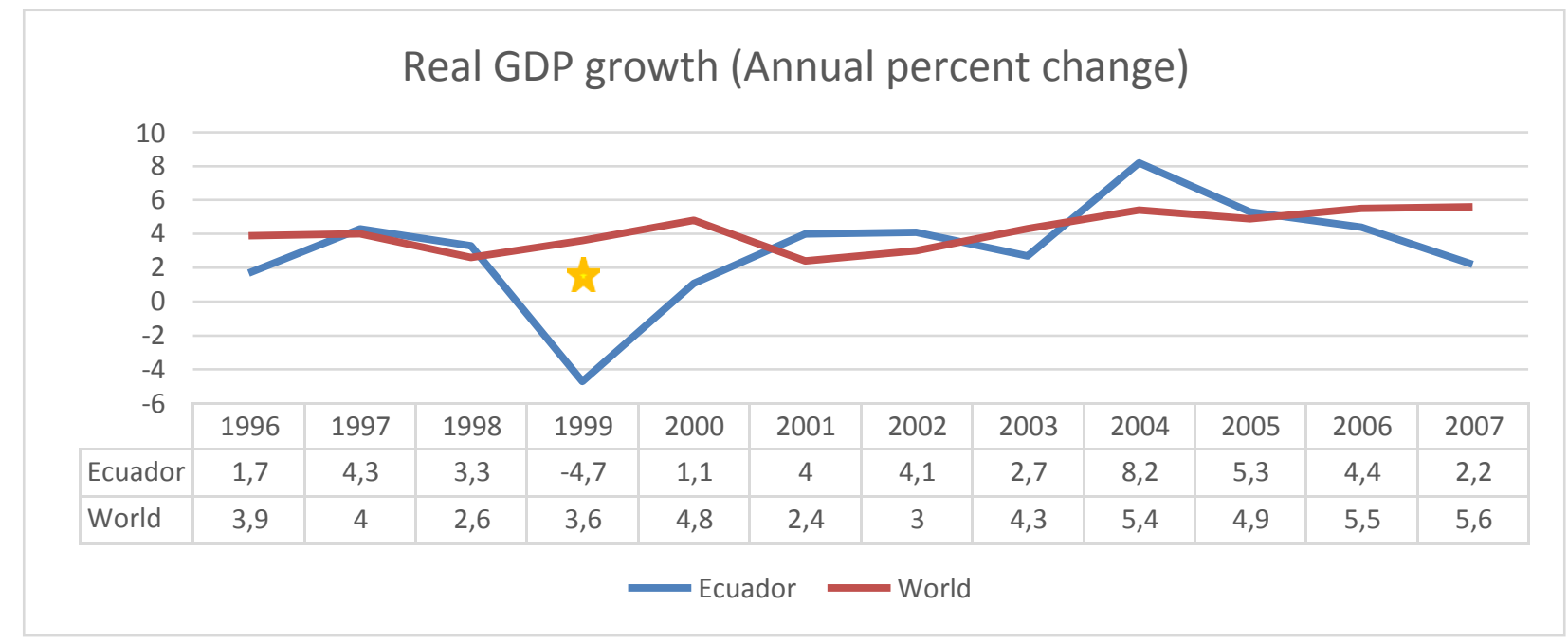

Source, IMF

Gross domestic product (GDP) is the monetary value of all the finished goods and services produced within a country's borders in a specific time period. Though GDP is usually calculated on an annual basis, it can be calculated on a quarterly basis as well (in the United States, for example, the government releases an annualized GDP estimate for each quarter and also for an entire year). GDP includes all private and public consumption, government outlays, investments, private inventories, paid-in construction costs and the foreign balance of trade (exports are added, imports are subtracted). Put simply, GDP is a broad measurement of a nation's overall economic activity - the godfather of the indicator world. (Investopedia)

Another benefit of dollarization was the growth of the GDP, which grew 5 percent on average annually from 2000 to 2006, since GDP growth is affected by both inflation and interest rates, dollarization can be depicted as having an indirect positive effect on Ecuador's economy growth. (Anderson, 2016) 
As GDP is commonly used as an indicator of economic health, it can concurrently be used to make assumptions regarding the standard of living among population. (Kess, 2013)

If compared data before dollarization, Ecuadorian economy in terms of GDP had a significant change, despite the political instability that hit the country in the following years the growth remained relatively stable.

Another consequence of the economic crisis was the high levels of migration, this activity contributed to the development of a new source of income, one of the biggest ones after the oil exports, the income of remittance transfer of US 1.4 million represented on average $7 \%$ of the GDP for the 2002-2006 period, generating in this way an increment in levels of consumption in the Ecuadorian households.

\section{Exports}

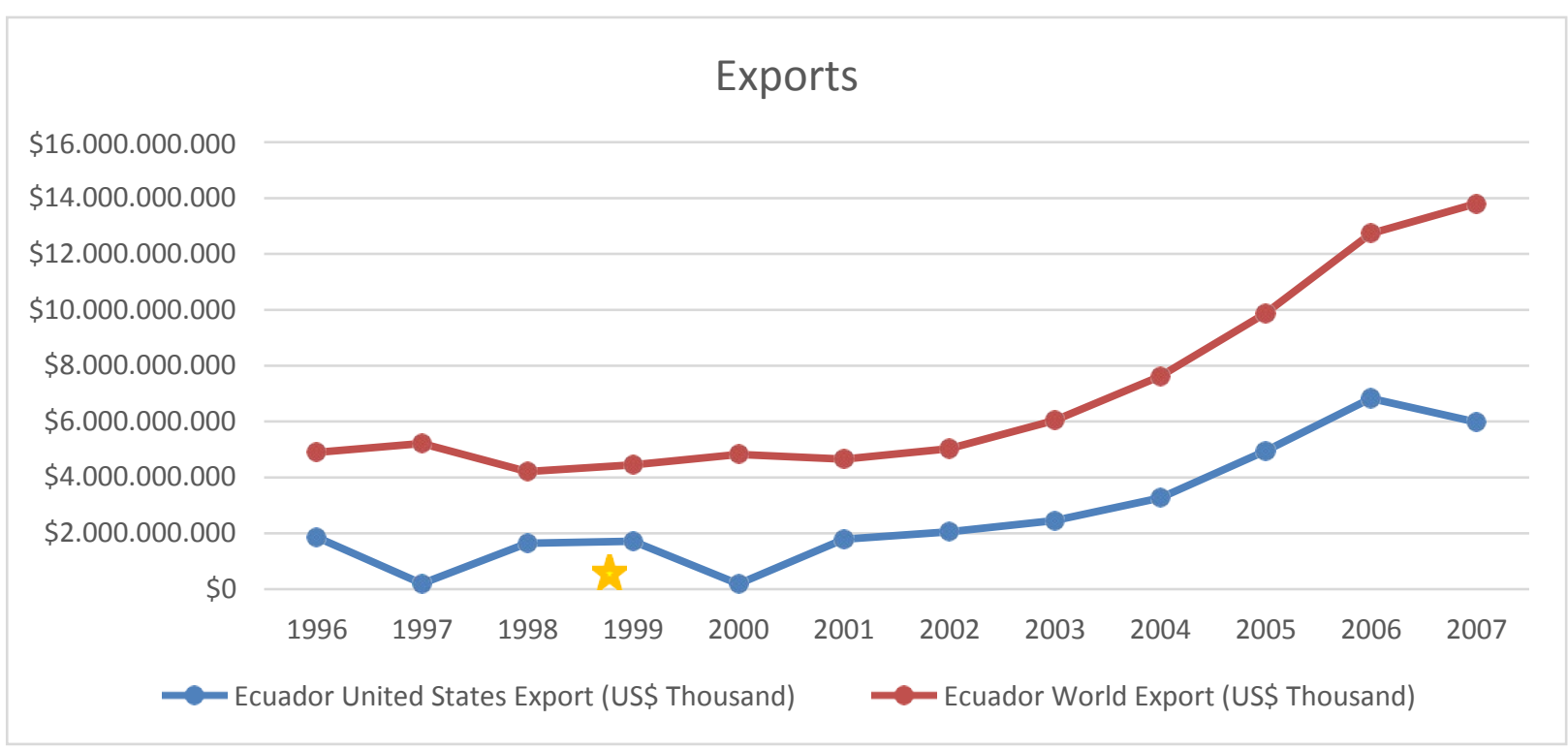

Source, WITS

\section{Vol. 4, núm. 4, octubre 2018, pp. 3-24}


In previous years of dollarization, the drop in exports in 1998 stands out, linked to the effects caused by the "Femonemo Del Niño" and the oil prices dump, exports started to show a slow recovery during 1999.

During dollarization period exports show growth in 2000, even though by 2001 descended again (-5.9\%), finally by the end of 2002 exports show growth and reached US 5.000 million, a similar value registered in 2000 .

Ecuadorian economy has characterized by being strongly dependent of the exportation of primary products, banana, cacao, shrimps, and oil; as a consequence the economy is rather sensitive to the volatility of international pricing of those products and climate changes that may affect the recollection of them.

$47.3 \%$ of Ecuadorian exports are destined to the United States, given to this case of dollarization some stability to the exports. Countries that are part of the European Union constitute the second most important destination with a participation of $12.32 \%$, Peru $7.95 \%$, Colombia $4.97 \%$, Chile $4.94 \%$, Venezuela $3.04 \%$ and other countries with unrepresentative percentages. The evolution of export to different destinations shows a tendency to grow in the last 15 years.

Exports growth are settled here as a benefit because a big portion of Ecuadorian exports goes to the United States, so as the graphic illustrates, the trade partnership with the US shows a steady growth after dollarization. But is important to acknowledge that exports with the USA growth due to the elimination of currency exchange rates, since after 2000 both countries shared the same currency, the trading costs became lower and so it also became easier to sell products to North 
America. Dollarization helped to stimulate commercial integration, through the improvement of macroeconomic stability and lower transaction costs associated with currency exchange ${ }^{2}$.

Foreign Direct Investment

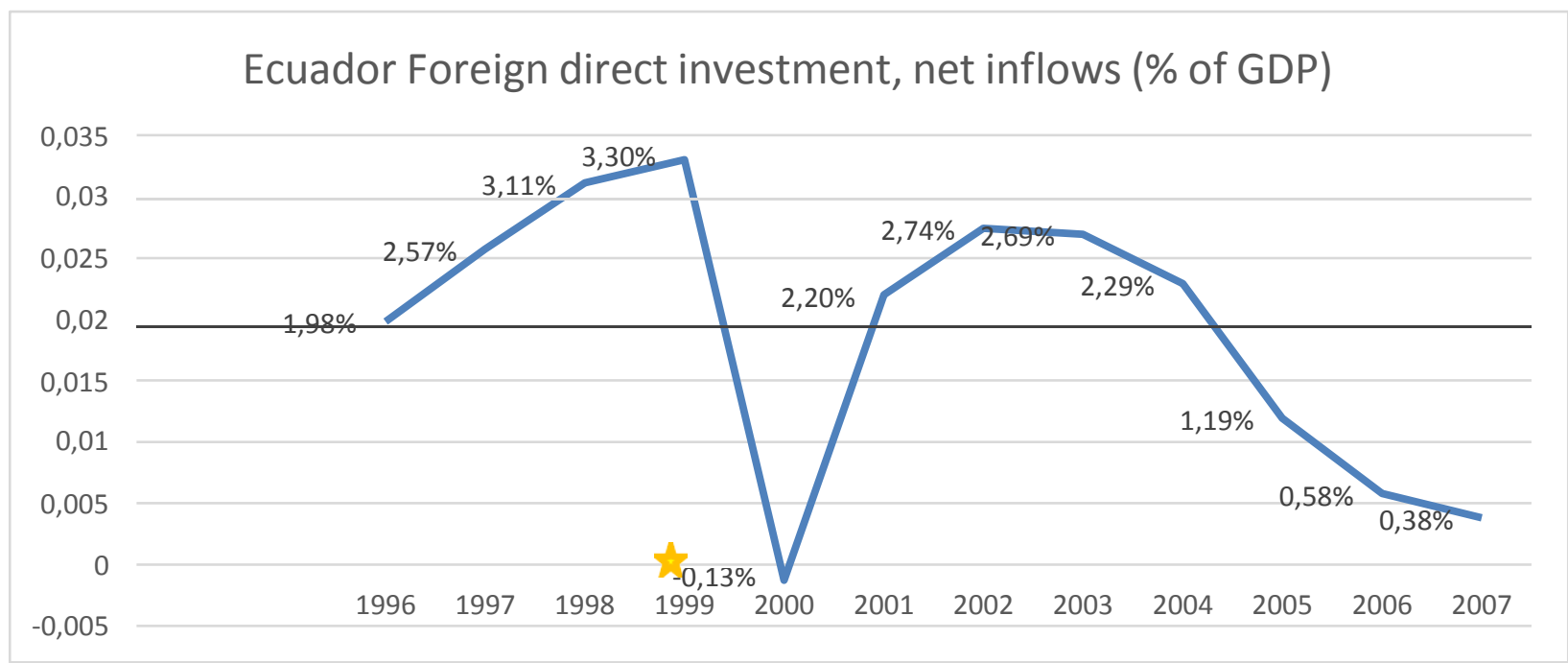

Source, IMF

The literature analyzing the impact of Foreign Direct Investment in a newly dollarized economy agrees with the idea that, a dollarized economy would eliminate currency exchange risk and would send a strong signal to foreign investors that the government policy is geared to longterm growth and stability. This could lead to increased foreign direct investment and additional growth compared to a scenario where a national but unstable currency is the medium of exchange. (Alan Karnovitz, 2010)

The adaptation of the USD brings many benefits including the mitigation and minimization of inflationary risk in the long and short term, an increase in foreign direct investment (FDI), capital

\footnotetext{
${ }^{2}$ Exports will be again analyzed in the dollarization costs section.
}

\section{Vol. 4, núm. 4, octubre 2018, pp. 3-24


flow inward, a sustainable store of value, and helps to stabilize the exchange rate and increases confidence among consumers and easier financial integration into the global economy (Essays, 3017)

The first major event that positioned Ecuador in the international market was the cocoa boom ${ }^{3}$ that started at the end of the $19^{\text {th }}$ century. This event also leads the Ecuadorian economy to become one ruled by the exportation of primary goods. ${ }^{4}$ The 70 s were the start of the petroleum boom, which introduced a change in the Ecuadorian economic structure. As result of the growth of the price and volume of the oil exports, several economic sectors experienced growth. However, it was not possible to lay solid foundations for a harmonious and sustained development, and rather, a series of imbalances of internal and external order were accumulated, which became evident in the 1980 s. $^{5}$

By the 80 s due to a not so flexible legislation, Ecuador FDI is just US 85 million $^{6}$ on average but by the 90 s changes in the legal framework made the arrival of foreign investment viable. The Ecuadorian experience shows that foreign capitals are very sensitive to the political or economic instability of a country.

\footnotetext{
${ }^{3}$ Cocoa Boom, in the last part of the 19th century, the good weather conditions of the coast and the Ecuadorian highlands began to be exploited to obtain cocoa. Quickly the small farmers realized that they could easily harvest the product obtaining excellent margins of profit. With the arrival of the 20th century, Ecuador became the largest producer of cocoa worldwide, exporting its product mainly to Europe, Japan, and the United States. The cacao cultivated in the sierra was destined for local consumption, while the one obtained in the coastal zone was exported.

${ }^{4}$ Cocoa beans were the main export between 1900 and 1925, bananas between 1948 and 1970, and oil from 1972 onwards.

${ }^{5}$ a subsequent fall of oil prices coupled with the effects of natural disasters such as the 1982-1983 El Niño phenomenon and 1987 earthquake, which destroyed the country's main oil pipeline and forced the suspension of oil production for several months, underscored the fragility of Ecuador's economy and its vulnerability to exogenous factors. (Fleury, 2008)

${ }^{6}$ Ecuador Central Bank data.
}

\section{Vol. 4, núm. 4, octubre 2018, pp. 3-24}


By the end of 1998 and through 1999 Ecuador situation was complicated in economic and political terms, problems that lead to dollarization; the impact on the FDI was evident in 1999 falling $23.5 \%$ in relation to 1998 .

COSTS

Absence of monetary policy

The international experience review shows that after implementation of fixed exchange rate regimes such as currency - boards or official dollarization, as well as creation of monetary unions, many questions about the existence and role of central banks arise. When central banks lose their traditional function of issuing money and their discretional power to use monetary and exchange rate policy. (PICO, 2004). The central bank is unable to have its own monetary policy ${ }^{7}$. The use of the U.S. dollar as legal tender means that one of two instruments for influencing the economy is unavailable to the government. (Wang, 2016). Without monetary policy, if there is fiscal deficit, the Central Bank would have to use debt or taxes in order to reduce or eliminate the deficit.

\footnotetext{
${ }^{7}$ Macroeconomic policies are usually divided into demands-side (monetary and fiscal policy) and supply side policies. Monetary policy refers to the use of interest rates, money supply and exchange rate in order to influence the level of economic activity in a country.
}

\section{Vol. 4, núm. 4, octubre 2018, pp. 3-24}




\section{$D E B T$}

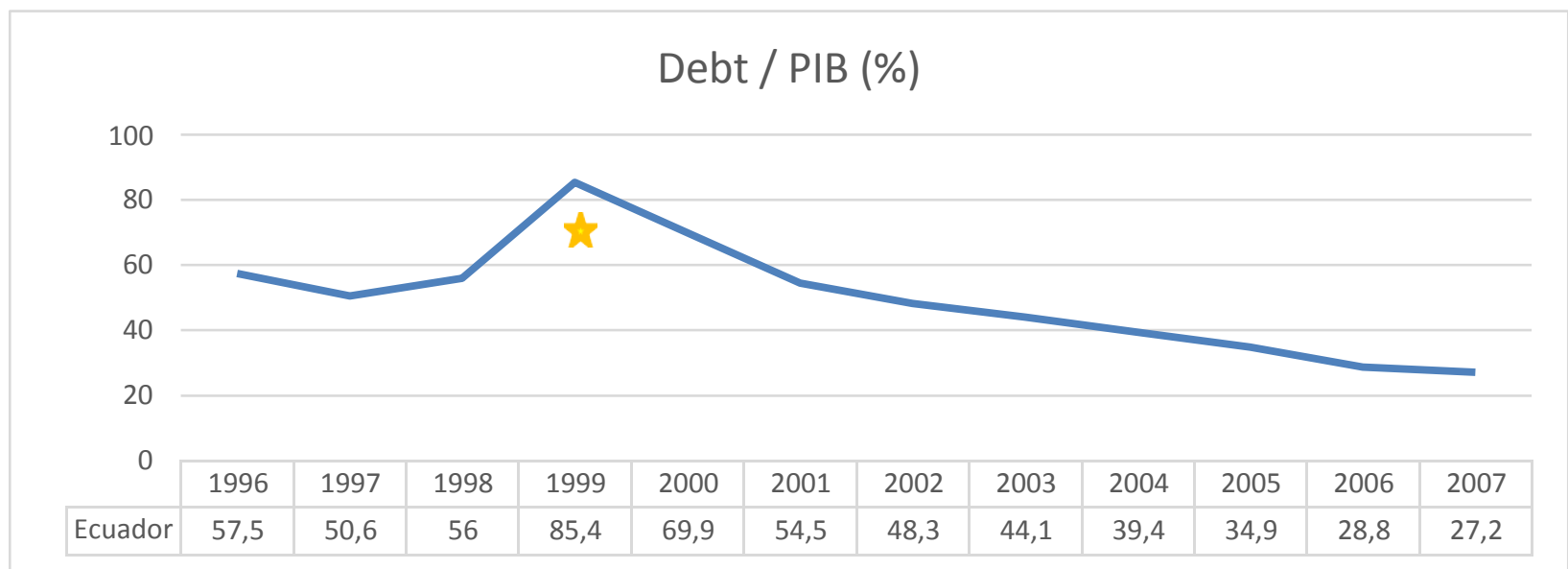

Source, Ecuador Central Bank

The evolution of public debt in Ecuador have been defined not only by dollarization but by some other external factors; in 1999 Ecuador had the highest level of debt, it was the result of damages because of El Niño, which caused serious harms to the road and health infrastructure along the Coast, an estimate for rehabilitation cost is around US 2869 million $^{8}$, most of the negative effects hit the productivity sector, especially the agriculture and fishing sector.

Even though the graphic shows that the percentage of debt tends to decrease overall the upcoming years, this is thanks to the dollarization process, when compared with the high amount of debt in 1999. Since the period before dollarization was especially critical to the country, due to all the factors that contribute to its instability, the period after dollarization just shows the attempt of the Central Bank to recover some stability.

${ }^{8}$ ECLAC data.

16 Vol. 4, núm. 4, octubre 2018, pp. 3-24

Carmen Álvarez-Vásquez; Víctor F. Guaranda-Sornoza; Lilian del Jesús Aguilar-Ponce; Antonio E. Pinargote-Vásquez; Diana K. Zambrano-Ponce; Jessenia H. Morán-Chilán 
After dollarization, the ratio Debt/GDP is still considered high, according to the Ecuadorian Normative, the legal limit of public indebtedness is $40 \%{ }^{9}$ and by 2016 the percentage of debt was about to reach this limit, Which is a clear sign that the need to acquire public debt is one of the biggest disadvantages of fully dollarizing the Ecuadorian economy.

It is worth mentioning that in 2009 the public debt reached one of the lowest points of debt as result of having declared a section of the debt "illegitimate". ${ }^{10}$ As consequence of this move the principal lenders of the country took back their support and the Government had to look for another kind of financing, that's how in the same year Ecuador found in China a new commercial partner; marking the beginning of the Chinese financing, which by the end of 2016 reached a total of US 8 650 million $^{11}$, which represents $8 \%$ of the Gross Domestic Product (GDP) of the country.

\footnotetext{
${ }^{9}$ Organic Code of Planning and Public Finance, article 124.

${ }^{10}$ In November 2008, Ecuador became the first country to undertake an examination of the legitimacy and structure of its foreign debt. An independent debt audit commissioned by the government of Ecuador documented hundreds of allegations of irregularity, illegality, and illegitimacy in contracts of debt to predatory international lenders. The loans, according to the report, violated Ecuador's domestic laws, US Securities and Exchange Commission regulations, and general principles of international law.

${ }^{11}$ Ministry of Finance Data
}

\section{Vol. 4, núm. 4, octubre 2018, pp. 3-24}

17 Carmen Álvarez-Vásquez; Víctor F. Guaranda-Sornoza; Lilian del Jesús Aguilar-Ponce; Antonio E. Pinargote-Vásquez; Diana K. Zambrano-Ponce; Jessenia H. Morán-Chilán 


\section{MORE TAXES}

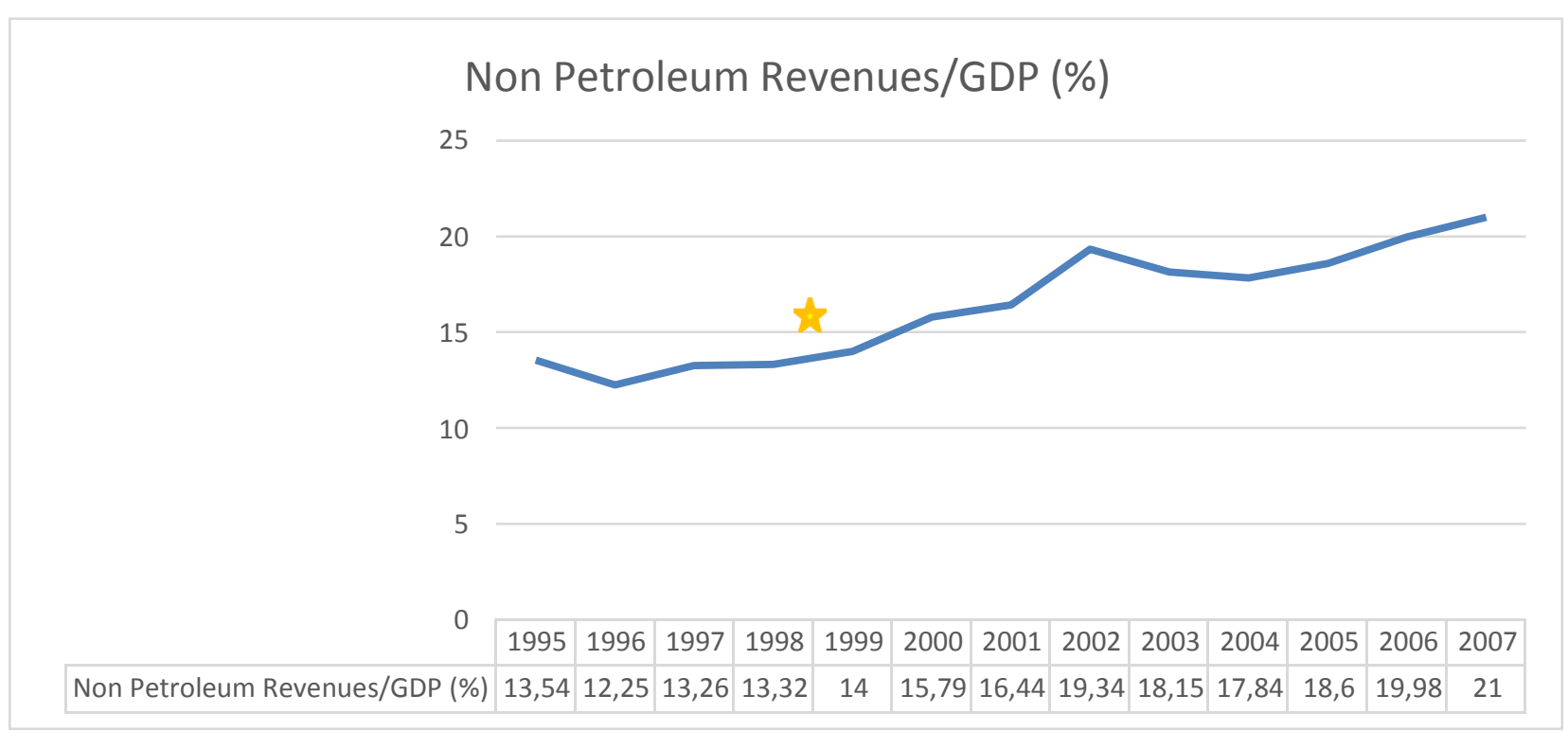

\section{Source, Ecuador Central Bank}

The most efficient way to increase the income in the country has been through tax collections; by increasing them in a sustained manner, as a result of this, the country had had many tributary reforms in the last years, reforms that have allowed the state to collect more money in order to cover debt.

Tax revenue has incremented greatly in Ecuador, from 1997 to 2006 the revenues from taxation were US 26000 million, in comparison, the same amount was collected in only 4 years, from 2007 to $2010^{12}$, This rise is explained by the increase in rates, the creation of taxes and the modifications of existing taxes. By 2007 oil income represented $21 \%{ }^{13}$ of the total State incomes but tax income accounted $45 \%$ of the total revenues.

${ }^{12}$ Center for Fiscal Studies of Ecuador

${ }^{13}$ Ecuavisa data

\section{Vol. 4, núm. 4, octubre 2018, pp. 3-24}


By 2016 is reported that Ecuadorians paid a total of $30^{14}$ different kinds of taxes, including a Capital Outflow $\operatorname{Tax}^{15}$, which was created with the aim of preventing the outflow of dollars from Ecuador in order to avoid weaken dollarization.

\section{Exports Growth compared other South American countries}

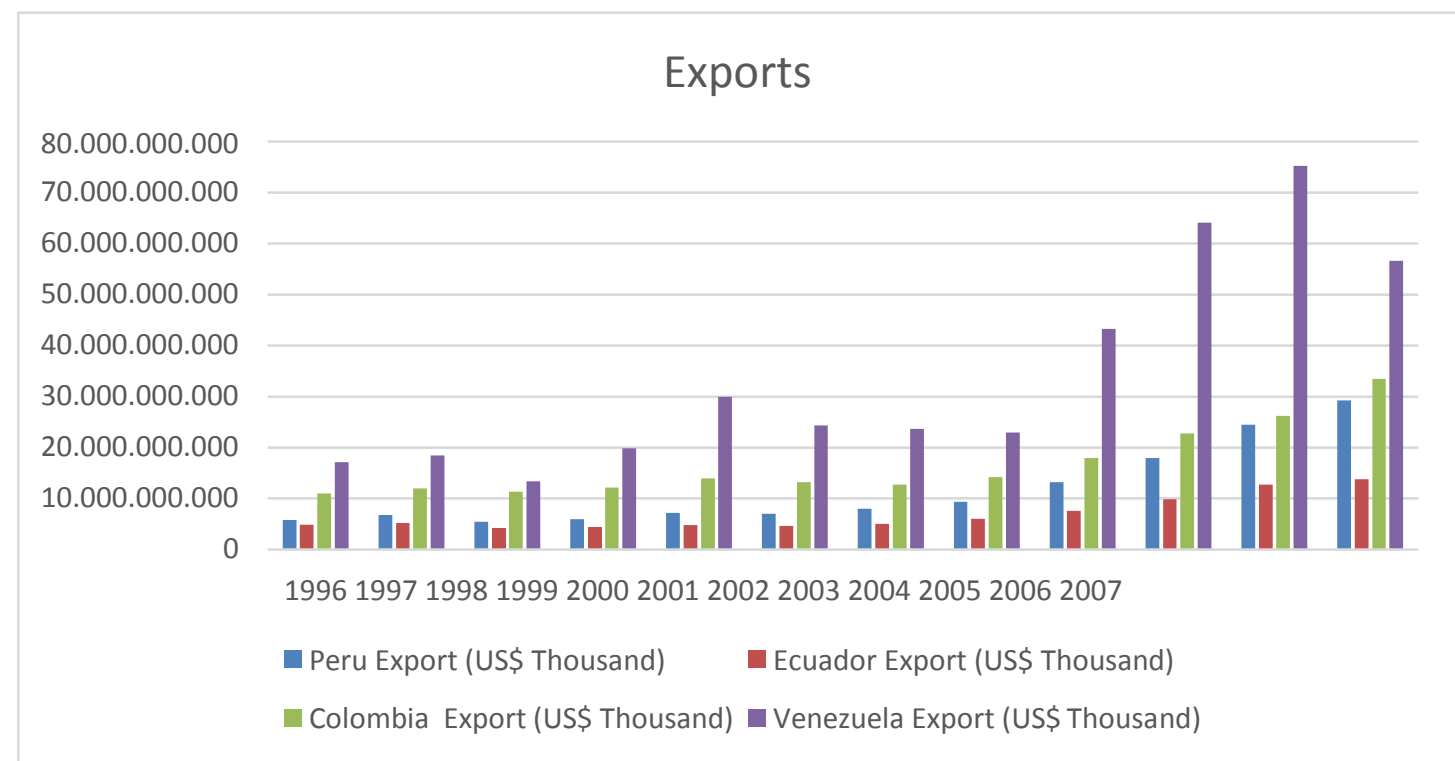

Source, Index Mundi

The absence of monetary policy, besides making it harder for the government to intervene during times of recession, has an adverse effect on exports. A weak domestic currency stimulates exports, and a strong domestic currency makes the country's exports less competitive in the international market compared to goods from other countries (Staff, 2017).

Dollarization influenced exports in two different ways, first as it was mentioned before, favored the USA-Ecuador transactions. But also it cannot be forgotten that dollarization may have

\footnotetext{
${ }^{14}$ Ecuador's Internal Revenue Service

${ }^{15}$ ISD, applies to remittances abroad in cash or by check, transfers or withdrawals of any kind made with or without the intermediation of financial entities and, in general, any other mechanism for extinguishing obligations.
}

\section{Vol. 4, núm. 4, octubre 2018, pp. 3-24}


weakened the competitiveness of the country in comparison with other South American economies which are the principal competitors of Ecuador in the international market. Those competitors' countries had the possibility of devaluating their currency and are able to maintain or even reduce the prices of their exportable products while Ecuadorian exporters lack this competition tool.

Given this context, the loyalty of external markets relies on the analysis of the variation of currency quotation from competitor's countries. A rise in the price of the US dollar against the national currencies of the buyer countries or devaluations programmed by governments of those countries will mean an appreciation of the dollar and therefore a loss of competitiveness of the Ecuadorian products; inversely, a decrease of the price of the dollar against the national currency of the purchasing countries, will mean a depreciation of the dollar and therefore, a greater competitiveness of Ecuadorian products.

That is the case of Ecuador, when comparing the Ecuadorian export trends with close countries like Colombia, Venezuela, and Peru, it can be observe the development of their exportations is greater than the one Ecuador had have in the same period of time

\section{Conclusions.}

Dollarization in Ecuador was taken as an extreme measure to try to stabilize an economy that was going through a chaotic period; according to the data collected and the statistics analyzed, the country recovered macroeconomic balances after the policy was implemented. Of course, the first years were rough for Ecuadorian economy since it can be said that was a transition period. But the upcoming years showed signs of a recovering economy. 
Perhaps as it was mentioned before it was an extreme measure, but if not taken at the moment the economy would have kept its tendency to shrink instead of developing. Today Ecuador is the ninth largest economy in Latin America ${ }^{16}$; but also favorable conditions in the world economy have contributed to a steady improvement in Ecuador's macroeconomic conditions ${ }^{17}$.

The biggest benefit of dollarization was the reduction of inflation rates; which lead to an overall stabilized economy and a sustained buyer power of Ecuadorian people. It also gave to the national industry a sense of confidence to improve production without the fear of a devaluation of the currency would generate unforeseen losses. The stability that dollarization generated allowed companies to improve its production capacities to cover the demands of the internal and external market. Foreign investment was also attracted by the perceived stability that USD gave to Ecuador, the sum of all those benefits contributed to the sustained growth of GDP.

The main disadvantage I found was that Ecuador would have to rely in the changes of the political economy of the US, considering that the decisions made will not contemplate or take into account the economic requirements of Ecuador; also one of the main concerns of a dollarized country is to be able to have enough dollar reserves in its Central Bank and from international reserves, as to avoid negative consequences from external eventualities like drops of the price of petroleum or the economic effects of natural disasters.

Overall I believe that Ecuador got more benefits than costs in the process of dollarization. Even though it was an aggressive and rapid change for the economy, the performance of the country improved after 2000. Ecuador lived a dark economic period before dollarization, it was hit by

\footnotetext{
${ }^{16}$ Trading Economics

${ }^{17}$ High oil prices in the international market and a depreciating dollar have supported the strongest growth of the economy.
}

\section{Vol. 4, núm. 4, octubre 2018, pp. 3-24}

21 Carmen Álvarez-Vásquez; Víctor F. Guaranda-Sornoza; Lilian del Jesús Aguilar-Ponce; Antonio E. Pinargote-Vásquez; Diana K. Zambrano-Ponce; Jessenia H. Morán-Chilán 
several factors that contributed to the destabilization of the economy, if the measure wouldn't have been taken the most likely scenario was the instability would have continued, shrinking more and more the economy. Dollarization requires the adoption of special prudential measures. The banking system must be able to withstand significant exchange rate adjustments, as well as possibly largerthan-normal swings in capital flows.

\section{Annexes}

\section{Measuring Benefits}
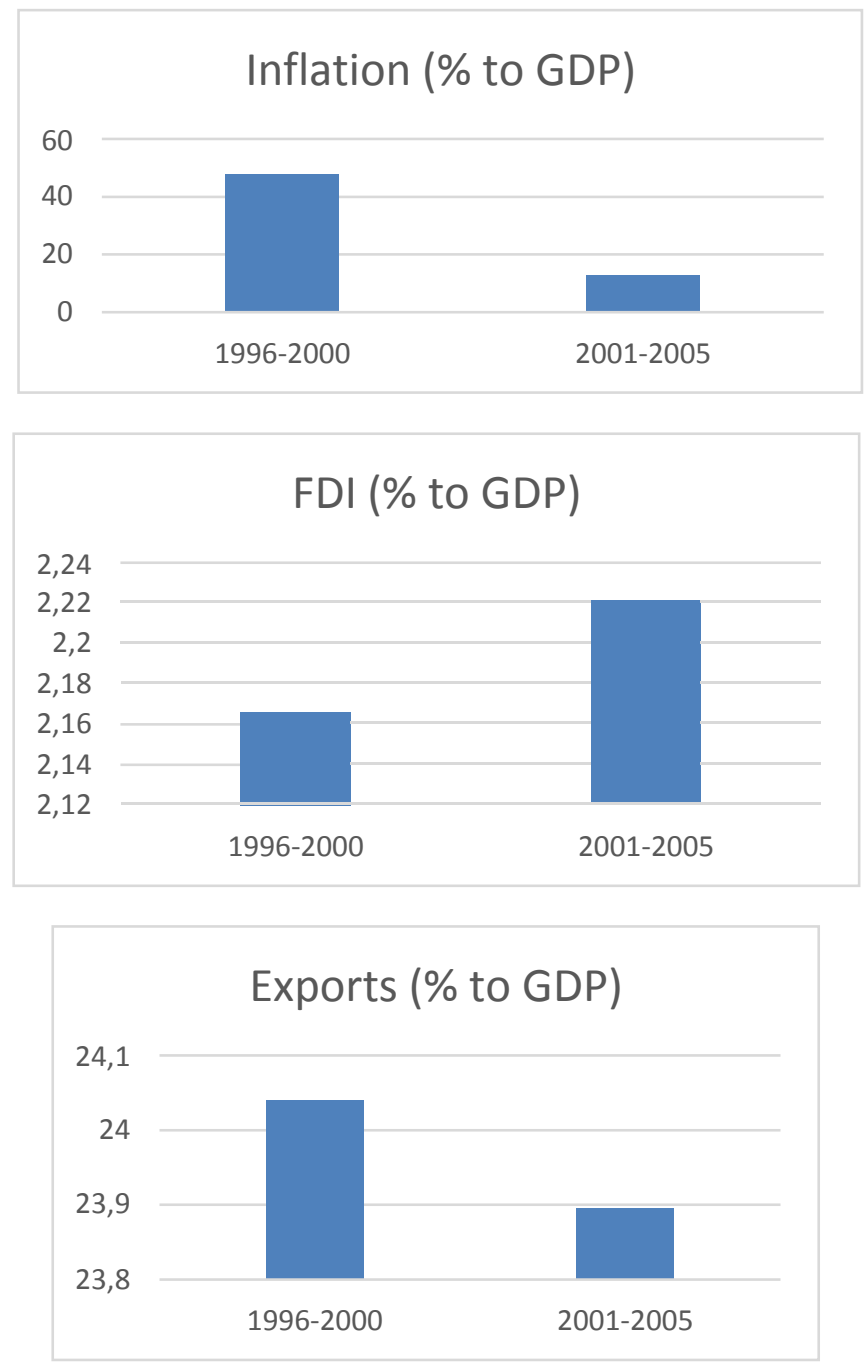

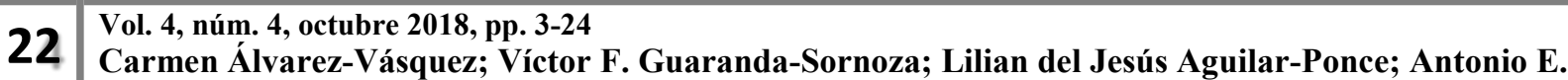
Pinargote-Vásquez; Diana K. Zambrano-Ponce; Jessenia H. Morán-Chilán
} 


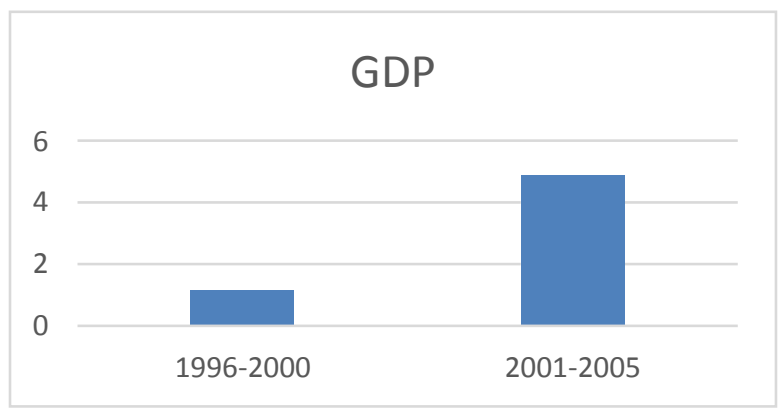

\section{Measuring costs}
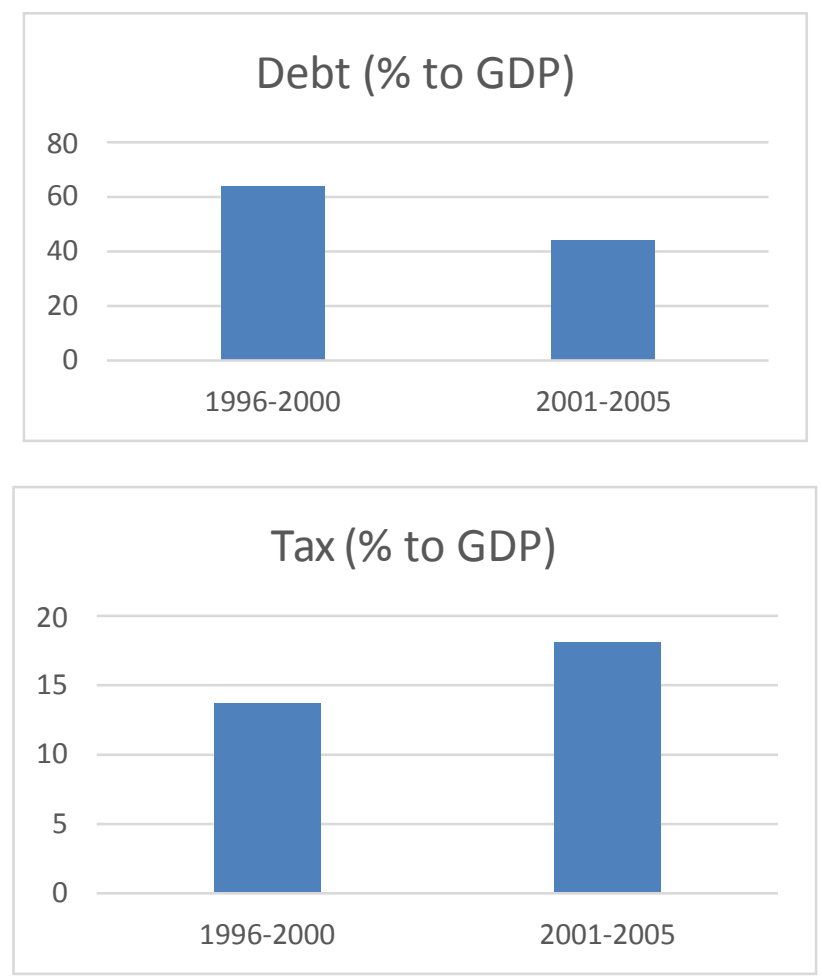

23 Vol. 4, núm. 4, octubre 2018, pp. 3-24

Carmen Álvarez-Vásquez; Víctor F. Guaranda-Sornoza; Lilian del Jesús Aguilar-Ponce; Antonio E. Pinargote-Vásquez; Diana K. Zambrano-Ponce; Jessenia H. Morán-Chilán 


\section{Bibliography.}

Alan Karnovitz, S. M. (2010). An Assessment of Alternative Monetary Regimes for a Future Palestinian State: Dollarization versus a National Currency. MFI - USAID, 17.

Anderson, A. (2016). Dollarization: A Case Study of Ecuador. Journal of Economics and Development Studies, 5.

Bank, E. C. (s.f.).

Bank, T. W. (2000). World Bank. Obtenido de The World Bank: http://web.worldbank.org/archive/website00960A/WEB/OTHER/B8099E91.HTM

Erazo, P. M. $(9$ de Enero de 2010). BBC. Obtenido de http://www.bbc.com/mundo/economia/2010/01/100108_0053_dolarizacion_ecuador_jaw

Essays, U. (3017). UK Essays. Obtenido de https://www.ukessays.com/essays/economics/theeffects-of-inflation-economics-essay.php

Fleury, S. (2008). Assessment of development results: Ecuador. UNDP.

Heakal, R. (s.f.). Investopedia. Obtenido de https://www.investopedia.com/articles/04/082504.asp

Investopedia. (s.f.). Obtenido de https://www.investopedia.com/terms/g/gdp.asp

Kess, J. K. (2013). Monetary Integration: Thirteen Years of Dollarization on Ecuadorian Economics, 2000-2013 . Global Advanced Research Journal of Management and Business Studies, 16.

PICO, M. G. (2004). Funciones de un banco central que pierde el control de la política monetaria y cambiaria: el caso ecuatoriano y revisión de la experiencia a nivel internacional. Cuestiones Economicas, 29.

Staff, I. (2017). Interesting Facts About Imports and Exports. Obtenido de https://www.investopedia.com/articles/investing/100813/interesting-facts-about-importsand-exports.asp

Wang, S. (2016). Examining the Effects of Dollarization on Ecuador. Council on Hemispheric Affairs, 6. 